\title{
An Overview of Crimes, Terrorism and DNA Forensics in Pakistan
}

\author{
Mian Sahib Zar*, Ahmad Ali Shahid and Muhammad Saqib Shahzad
}

Centre of Excellence in Molecular Biology (CEMB), University of the Punjab, Lahore, Pakistan

\begin{abstract}
Crimes and terrorism are very common in Pakistan from the last unfortunate decade of war on terror which have genuinely inculcated a psychological terror in the minds of both affected and unaffected families. The number of crimes, suicide attacks and target killing are increasing in Pakistan day by day. The total 15 suicide attacks were carried out in Pakistan from 2002 to 2005, while in the next four years (2006-2009) it was increased to 200 and now it is more than 372. Pakistan needs to promote forensic science in order to control crimes and terrorism. Unfortunately, most of the crimes remain untraced due to the lack of technical expertise and proper research in this field.
\end{abstract}

\section{Keywords: Crimes; Terrorism; Forensics; Pakistan}

\section{Introduction}

Since 2002, Pakistan has been engaged in fighting against crimes and terrorism in the Federally Administered Tribal Areas (FATA), Karachi, Balochistan and some parts of the Khyber Pakhtunkhwa (KP) Province. According to a US bi-partisan report "World at risk 2008", all roads that lead to weapons of mass destruction, proliferation and terrorism led to Pakistan [1]. Unfortunately, an international impression is perfumed all over the world that Pakistan is the only country where terrorism of all kinds is found and nurtured without government hesitation. The number of suicide attacks and target killing in Pakistan are increasing with the passage of time [2]. The total number of suicide attacks in Pakistan was 15 in 2002-2005, while it was increased up to 200 in 200609 and now it is more than 372 (www.satp.org/satporgtp/countries/ pakistan/database/Fidayeenattack.htm). The News reported on March 24, 2010 that during the period from 2002 to mid-March 2010, a total of 7,739 terrorist incidents had occurred in Pakistan which had resulted 8,875 deaths of both security personnel and civilians. Some three million people have been displaced because of war on terror and insecurity [3].

\section{Current capabilities of forensic DNA profiling in Pakistan}

Currently few forensic laboratories are available for DNA profiling in Pakistan such as National Forensic Science Agency, Punjab Forensic Science Agency and Centre for Applied Molecular Biology (CAMB) DNA Forensic Laboratory, but unfortunately these labs are still not well developed. Efficient and well-functioning Forensic DNA laboratories are necessary in Pakistan, particularly in Karachi, Balochistan, FATA and Khyber Pakhtunkhwa province of Pakistan to overcome crimes and terrorism. Pakistani citizens have stronger desires for DNA profiling and the government of Pakistan is trying to develop a national DNA database of all its citizens [4]. The benefit of this DNA database will be to link it with currently available biometric based computerized National Identity Card (NIC) system to search out criminals and terrorist and finally to identify suicide bombers and victims of accidents, i.e., man-made as well as natural disasters and military conflicts. For implementation of this system in Pakistan, a meeting has already been decided between civilian and military law enforcement agencies that National Database and Registration Authority (NADRA) would develop and maintain a biometric database of criminals and terrorists and would make a tree of their all family members which will be easily available to law enforcement agencies [4]. After the terrorists attack on Pakistan Naval Shipping Mehran Base in the largest city of Pakistan (Karachi), DNA tests were carried out to identify the terrorists, but it was found that the terrorists were not registered Pakistanis because their profiles were not matched with the NADRA database [5]. Recently Punjab government in Pakistan has established the world second largest forensic laboratory (Punjab Forensic Science Agency) in Lahore to counter terrorism and help police department in the investigations of criminals. This forensic laboratory has 14 different forensic disciplines, including DNA and serology, toxicology, pathology, forensic photography, computer forensics, narcotics, death scene investigation, crime scene investigation, trace chemistry, firearms and tool marks, latent prints, questioned documents, polygraph and audiovisual. The government of the Punjab is also trying to make collaboration with different renowned forensic institutes of the world to get their support for strengthening and development of the laboratory [6].

\section{Gaps and flaws in DNA profiling in Pakistan}

There are so many gaps and flaws in DNA profiling in Pakistan. These are lack of experts in this field, lack of funds and chain of custody, inadequate training and equipment, lack of awareness, no communication between forensic DNA analysts with forensic DNA researchers [7]. Pakistani DNA analysts are not updated with the current DNA research work in forensics. They need special training in this field and they need to keep communication and collaboration with different forensic research institutes within country and out of country.

\section{Forensic research institutes in Pakistan}

There are only few institutes in Pakistan who have started research work in DNA forensics, including Centre of Excellence in Molecular Biology (CEMB) University of the Punjab Lahore, University of Veterinary and Animal sciences Lahore and Government College University Lahore Pakistan. CEMB Forensic Research Laboratory is a dedicated laboratory in Pakistan which engaged in forensic DNA research since 2005, and it provides facility of DNA testing services in criminal cases, paternity disputes and mass disasters.

*Corresponding author: Mian Sahib Zar, Centre of Excellence in Molecular Biology (CEMB), University of the Punjab, Lahore, Pakistan, Tel: +92-333-9701436; E-mail: msahibzar@yahoo.com

Received September 11, 2013; Accepted September 25, 2013; Published September 30, 2013

Citation: Zar MS, Shahid AA, Shahzad MS (2013) An Overview of Crimes, Terrorism and DNA Forensics in Pakistan. J Forensic Res 4: 201. doi:10.4172/21577145.1000201

Copyright: ( 2013 Zar MS, et al. This is an open-access article distributed under the terms of the Creative Commons Attribution License, which permits unrestricted use, distribution, and reproduction in any medium, provided the original author and source are credited. 
Citation: Zar MS, Shahid AA, Shahzad MS (2013) An Overview of Crimes, Terrorism and DNA Forensics in Pakistan. J Forensic Res 4: 201. doi:10.4172/2157-7145.1000201

Page 2 of 2

\section{Conclusion}

This study highlights the immediate need and importance of forensic science and research in Pakistan in order to overcome crimes and terrorism. This would be highly respectable to every citizen of Pakistan at first because this control would deploy the inescapable compulsion over the freedom and liberty of people. Another most important and dignified impact would be for the International World especially for those who want to visit Pakistan because now days the foreigners feel deeply insecure to come inside. The only factor behind this unfortunately defamed and notorious reputation is the psychological impression of frequent crimes, incessant suicide bombings and the most repellent factor is widely proliferated terrorism. Here are interesting fact behind the immediate need of forensic sciences and research are that the country would willingly start struggle in every field because the control of the above mentioned hazarded factors will bring prosperity in all sectors whether it is political, social, psychological, and economical and most importantly would the value of human beings. Due to the humanitarian sympathy, the research of the forensic sciences would be considered as a famous and noteworthy miracle of the Pakistani society.

\section{References}

1. Graham B, Jim T, Graham A, Robin C, Steve R, et al. (2008) World at Risk: The Report of the Commission on the Prevention of WMD Proliferation and Terrorism. THE AUTHORIZED EDITION, Vintage Books, New York, USA and in Canada by Random House of Canada Limited, Toronto. ISBN: 978-0-30747326-4.

2. For year-over-year data, www.satp.org/satporgtp/countries/pakistan/database/ Fidayeenattack.htm.

3. Mahmood S (2010) The Strategic Dialogue between Reluctant Allies: The United States and Pakistan today.

4. http://www.nation.com.pk/pakistan-news-newspaper-daily-english-online/ Politics/08-Apr-2010/Govt-planning-to-have-citizens-DNA-database-Malik

5. http://www.pakistantoday.com.pk/2011/06/pns-attackers-were-foreigners-dnareport-reveals/.

6. http://www.nation.com.pk/pakistan-news-newspaper-daily-english-online/ Regional/Lahore/12-Jan-2011/Worlds-second-largest-forensic-lab-set-up-inCity.

7. Kayani SA (2011) Global War on Terror: The Cost Pakistan is Paying. Margalla Papers. 